\title{
Risk factors for patients with coronary heart disease hospitalized in Sanjiwani hospital Gianyar
}

\author{
A Santosa ${ }^{1 *}$ and P W Mahayana ${ }^{1}$ \\ ${ }^{1}$ Faculty of Medicine and Health Sciences, Universitas Warmadewa, Denpasar, Bali \\ *omangbabe@gmail.com
}

\begin{abstract}
The purpose of this study was to identify the risk factors of Coronary Heart Diseases (CHD) patients hospitalized in Sanjiwani Gianyar Hospital. This descriptive study used a cross-sectional design. Data collection were carried out based on the medical records of CHD patients hospitalized in Sanjiwani Gianyar during January to December 2016, which were selected by simple random sampling technique. The study research showed the majority $(91.3 \%)$ of CHD patients were aged $\geq 45$, male $(58 \%)$, and had no family history with cardiovascular disease (78.3\%). Most CHD patients had no smoking habit $(68.1 \%)$, had healthy BMI $(68.1 \%)$, had no diabetes mellitus history (65.2\%), and had hypertension history (55.1\%). Mostly, $84.1 \%$ of CHD patients had standard value of total cholesterol level, standard value of triglyceride level (62.3\%), suboptimal LDL level (52.2\%), and low HDL level (34.8\%). This concluded that most risk factors for CHD patients were aged $\geq 45$, male, had hypertension history and low HDL level as risk factors.
\end{abstract}

Keyword : Coronary, Hospitalized, Hospital Gianyar.

\section{Introduction}

Coronary heart disease (CHD) is a condition with inadequate blood supply to the cardiac muscle caused by coronary arteries obstruction [1]. The World Health Organization (WHO) in 2012 argued that cardiovascular disease was the number one cause of death in the world. One of them is CHD which is estimated to be the leading cause of death in developed and developing countries in 2020 [2]. Prevalence of CHD in Europe are around 20-40,000 people per 1 million population [3], while in the United States there are 450,000 deaths from CHD [4]

Statistical data in Indonesia shows an increase in the percentage of CHD patients from 1992 by $16.5 \%$ to $26.4 \%$ in 2000 . The prevalence of CHD in Indonesia in 2014 was around 883.447 people. Cases of hospitalization from non-communicable diseases in 2009 amounted to $40.53 \%$ and $40.03 \%$ in 2010 . Heart disease was the highest number of non-communicable diseases that caused deaths in hospitalized patients in 2009-2010 [5]. CHD is affected by various risk factors and have some severe complications that will end in heart failure and death. This study aims to determine the risk factors for patients with coronary heart disease who were hospitalized in Sanjiwani Hospital Gianyar

\section{Method}

\subsection{Data Collection}


The study was conducted at the Sajiwani Hospital in Gianyar from September to November 2017. This study was a descriptive observational study using a cross-sectional method using secondary data in the form of medical records. The populations in this study were all patients with coronary heart disease who were hospitalized in Sanjiwani Hospital Gianyar from January to December 2016. Samples that met the inclusion criteria were selected using simple random sampling technique, amounting to 69 people. Variables depending on this study are coronary heart disease. The independent variable consisted of age, sex, family history, smoking behavior, body mass index, history of diabetes mellitus, history of hypertension, and cholesterol levels.

The procedure for collecting data begins with a request for permission to the Medical Record Installation Section, then looks for and checks the completeness of the data in the medical record. Specifically for obtaining smoking behavior data, telephone interviews were conducted with all samples

\subsection{Statistical Analysis}

Data analysis was performed using the SPSS version 2.3 program. Data displayed in the narrative form includes tables and frequencies

\subsection{Ethical Consideration}

The study, the collection of clinical and epidemiological data was submitted for ethical approval to the Research Ethic Committee of Universitas Udayana, Denpasar. Enrolment of the study participants is conditional on appropriate consent.

\section{Results And Discussion}

The most sample were male. The main age range was 61-70 (30.4\%) years old. The study found as high as $6(8.8 \%)$ respondent with extremely old age 81-100 years old. Characteristic of Responden is list in table 1 . Twenty-seven $(39.1 \%)$ of the samples did not have jobs. The most of education level high school graduates is $24(34.8 \%)$ and does not attend school 4 $(5.8 \%)$.

Table 1. Characteristic of samples

\begin{tabular}{lcc}
\hline \multicolumn{1}{c}{ Characteristics } & Frequency & Percentage (\%) \\
\hline Gender & & \\
Men & 40 & 58.0 \\
$\quad$ Women & 29 & 42.0 \\
Occupation & 5 & \\
$\quad$ Civil servant & 6 & 7.2 \\
Private employee & 10 & 8.7 \\
Entrepreneur & 3 & 14.5 \\
Retired & 14 & 4.4 \\
Farmer & 4 & 20.3 \\
Laborer & & 5.8 \\
Education & 11 & \\
Higher education & 24 & 15.9 \\
Senior high & 22 & 34.8 \\
Junior high & & 31.9 \\
\hline
\end{tabular}




\begin{tabular}{ccc}
\hline Characteristics & Frequency & Percentage (\%) \\
\hline Elementary & 8 & 11.6 \\
No education & 4 & 5.8 \\
\hline
\end{tabular}

The study found $63(91.3 \%)$ of the sample age $\geq 45$ years old. Almost $54(78.3 \%)$ samples did not have a family history of cardiovascular disease; only $15(21.7 \%)$ samples had a family history of cardiovascular disease. Smoking behavior did not found in 47 (68.1\%). This study found $47(68.1 \%)$ samples with normal BMI, 14 (20.2\%) samples with overweight BMI. Samples that did not have a history of diabetes mellitus recorded $45(65.2 \%)$ people, 38 $(55.1 \%)$ samples with a history of hypertension. Detail CHD risk factors are listed in table 2

Table 2. Distribution of CHD risk factors

\begin{tabular}{ccc}
\hline \multicolumn{1}{c}{ Risk Factor } & Frequency & Percentage $(\%)$ \\
\hline Age & 6 & \\
$\quad$ < 45 years old & 63 & 8.7 \\
$\quad \geq 45$ years old & & 91.3 \\
Family history & 15 & 21.7 \\
$\quad$ Available & 54 & 78.3 \\
$\quad$ Unavailable & & \\
Smoking habit & 22 & 31.9 \\
$\quad$ Smoking & 47 & 68.1 \\
$\quad$ Not smoking & & \\
IMT & 8 & 11.6 \\
$\quad$ < 18.5 & 47 & 68.1 \\
18.5-24.9 & 14 & 20.2 \\
$\quad \geq 25$ & & 34.8 \\
DM history & 24 & 65.2 \\
$\quad$ Available & 45 & 55.1 \\
$\quad$ Unavailable & & 44.9 \\
Hypertension history & 38 & \\
$\quad$ Available & 31 & \\
Unavailable & &
\end{tabular}

Lipid profiles of the samples are list in table 3. The cholesterol levels, 58 (84.1\%) samples had normal total cholesterol levels and samples with high total cholesterol levels were only one $(1.4 \%)$. There were $43(62.3 \%)$ samples with normal triglyceride levels. There were no samples had very high triglyceride levels. Based on the distribution of LDL levels 36 (52.2\%) samples with sub-optimal LDL levels, $29(42 \%)$ samples with optimal LDL levels, and 4 (5.8\%) samples with LDL levels were high. No sample has high and very high LDL levels. The study found HDL levels, 24 (34.8\%) samples with low HDL levels, $23(33.3 \%)$ samples with high HDL levels, and 22 (31.9\%) samples with normal HDL levels.

Table 3. Lipid profile of the samples

\begin{tabular}{ccc}
\hline \multicolumn{1}{c}{ Variables } & Level & Percentage (\%) \\
\hline Total cholesterol & & \\
$<200$ & 58 & 84.1 \\
$200-239$ & 10 & 14.5 \\
$>240$ & 1 & 1.4 \\
Triglyceride & & \\
\hline
\end{tabular}




\begin{tabular}{|c|c|c|}
\hline Variables & Level & Percentage $(\%)$ \\
\hline$<150$ & 43 & 62.3 \\
\hline 150-199 & 24 & 34.8 \\
\hline 200-499 & 2 & 2.9 \\
\hline \multicolumn{3}{|l|}{ LDL } \\
\hline$<100$ & 29 & 42.0 \\
\hline $100-129$ & 36 & 52.2 \\
\hline $130-159$ & 4 & 5.8 \\
\hline 160-189 & 0 & 0 \\
\hline \multicolumn{3}{|l|}{ HDL } \\
\hline$>60$ & 23 & 33.3 \\
\hline $41-59$ & 22 & 31.9 \\
\hline$<40$ & 24 & 34.8 \\
\hline
\end{tabular}

The results of the study showed that the majority of samples were $\geq 45$ years old $(91.3 \%)$. The results of this study are in accordance with Zahrawardani et al. (2013), Novriyanti et al. (2014), and Torry et al. (2014), which found that most of the samples were $\geq 45$ years old (83.6\%), (98\%), and (90\%), respectively [6-8]. This finding relate to the elasticity of blood vessels will decrease with age, it can increase blood pressure, thereby facilitating the occurrence of the atherosclerosis process [9].

The male sample has the greatest frequency of suffering from CHD which is $58 \%$. The same results were obtained by Zahara (2013) and Yuliani et al. (2014), which showed that the sample of men had the highest proportion of each $(74.5 \%$ and $67.9 \%)$ [10,11]. According to the literature, men are more at risk of developing coronary heart disease than women and occur almost 10 years earlier. Women have protective hormone estrogen in blood vessels that plays a role in increasing HDL and decreasing LDL [12].

Based on the results of the study, $68.1 \%$ of the samples did not have smoking behavior, only $31.9 \%$ of the samples had smoking behavior. We did not evaluate association of the smoking with CHD event. The nicotine contained in cigarettes can damage the walls of blood vessels through the excretion of catecholamine neurotransmitters. The process also facilitates blood clotting because there is an increase in fibrinogen activity and platelet aggregation, thus facilitating the occurrence of atherosclerosis. The carbon monoxide (CO) contained in it also results in changes in structure and stronger binding to hemoglobin $(\mathrm{Hb})$. The bond between $\mathrm{Hb}$ and $\mathrm{CO}$ will reduce oxygen $(\mathrm{O} 2)$ red blood cells so that the oxygen supply to tissues including the myocardium becomes reduced [13].

Based on the results of the study of sample categories that had a normal BMI of $68.1 \%$, overweight BMI was $20.2 \%$, and underweight IMT was $11.6 \%$. The results of this study are in line with Sudayasa et al. (2014) who found that the majority of samples have normal BMI of each $65.3 \%$, and 76\% [14]. Body mass index associated with the metabolic syndrome consisting of dyslipidemia, diabetes mellitus, and hypertension which can increase the risk of suffering from cardiovascular disease. Increased body mass index is associated with increased levels of total cholesterol, triglycerides and LDL [9]

The results showed that $65.2 \%$ of the samples did not have a history of DM, and $34.8 \%$ of the samples had a history of DM. According to the literature, diabetes mellitus is a major risk factor for CHD by inducing hypercholesterolemia and increasing the risk of atherosclerosis [15]. The condition of hyperglycemia accompanied by oxidative stress can cause endothelial dysfunction, which is the initial process of atherosclerosis. The body's hyperglycemia will be responded to by the activation of an inflammatory reaction due to increased levels of Interleukin 18 (IL-18) and C-Reactive Protein (CRP) in the blood circulation. This condition 
will cause damage to the myocardium. Insulin resistance in DM patients can lead to thrombosis resulting in heart failure and increased risk of death.

The results of the study were $55.1 \%$ of the samples had a history of hypertension, and $44.9 \%$ of the samples did not have a history of hypertension. Similar results were obtained by Zahrawardani et al (2013), Yuliani et al (2014), and Novriyanti et al (2014) who found that the classification of blood pressure samples was dominated by hypertension as high as $69.5 \%$, $60 \%$ and $75 \%[6,7,10]$. Hypertension can damage the endothelium, which facilitates the process of atherosclerosis and triggers the occurrence of atherothrombosis so that it can cause CHD. The process of atherosclerosis will continue, the oxygen supply to the myocardium will decrease, while myocardial oxygen demand increases due to ventricular hypertrophy and increased cardiac workload. It is also aggravates the work of the heart by increasing the resistance of the left ventricle which causes longer dilatation and hardness of the heart, thus increasing the risk of death [16].

Based on the results of the study, $84.1 \%$ of the samples had total cholesterol levels $<200$ $\mathrm{mg} / \mathrm{dl}$. Total cholesterol levels above normal, the rest will stick and cholesterol deposition occurs. The blood vessel lumen will narrow, so that the process can increase the risk of CHD. Triglycerides in the intestine are converted to the form of chylomicrons, then hydrolyzed by the lipoprotein lipase enzyme so that it can be stored in the liver. Triglycerides in the liver will be synthesized into VLDL, in the blood VLDL will turn into IDL and eventually become LDL which is the main risk factor for the formation of atherosclerosis. High levels of triglycerides (> $200 \mathrm{mg} / \mathrm{dl}$ ) in the blood will increase the risk of CHD.2 Increased triglyceride levels can raise cholesterol levels in the blood, which can affect the process of atherosclerosis. The results obtained $52.2 \%$ of samples with LDL levels of 100-129 mg/dl. Research conducted by Zahara et al [11] also showed similar results, recorded that $30.6 \%$ of the samples had LDL levels of 100-129 mg/dl which were the highest frequency.

Cholesterol circulating in the blood is in the form of lipoprotein, $75 \%$ is LDL and $20 \%$ HDL. High LDL levels in the blood, most of which will accumulate in the arterial wall, when an endothelial injury occurs, LDL will enter the endothelium so that it will experience oxidation (Ox-LDL). Oxidized LDL will be phagocytosis by macrophages to form foam cells, which will secrete chemokine and cause smooth muscle cell transfer from tunica media to the intima. An increase in SMC in the intima can cause the formation of a fibrous cap, and if the rupture will trigger the formation of a thrombus that will clog the coronary arteries [9]. The results obtained $34.8 \%$ of samples with HDL levels $<40 \mathrm{mg} / \mathrm{dl}$. Similar results were obtained by Zahara et al (2013) which showed that more samples had HDL levels $<40 \mathrm{mg} / \mathrm{dl}$ as high as $64.3 \%$ [11]. HDL functions to take excess cholesterol in the blood vessel lumen to be carried to the liver, remove cholesterol from foam cells, and inhibit LDL oxidation which indirectly inhibits the process of atherosclerosis. Low levels of HDL can increase the risk of coronary heart disease because of the accumulation of cholesterol in the blood vessel lumen. The higher the LDL level in the blood plasma, the higher the risk of suffering from CHD, because LDL is the initial etiology of the process of atherosclerosis [9].

\section{Conclusions}

Based on the results of research and discussion, it can be described that the majority of CHD sufferers aged $\geq 45$ years, male sex, do not have a family history of cardiovascular disease and do not have smoking behavior. The body mass index of CHD patients is mostly 
normal, do not have a history of DM, although have a history of hypertension. Cholesterol levels of CHD patients were dominated by normal total cholesterol levels, normal triglycerides, moderate level of LDL and relatively low HDL level.

\section{References}

[1] Sanchis-Gomar F, Perez-Quilis C, Leischik R and Lucia A 2016 Epidemiology of coronary heart disease and acute coronary syndrome Ann. Transl. Med. 4(13)

[2] Ford E S and Capewell S 2007 Coronary heart disease mortality among young adults in the US from 1980 through 2002: concealed leveling of mortality rates Journal of the American College of Cardiology 50(22) pp 2128-32

[3] Rayner M and Petersen S 2000 European cardiovascular disease statistics edition Br Hear Found

[4] Armstrong D L, Wing S B and Tyroler H A 1995 United States mortality from ill-defined causes, 1968-1988: potential effects on heart disease mortality trends Int. J. Epidemiol. 24(3) pp 522-7

[5] Dinas Kesehatan 2014 Profil Kesehatan 2013 Kemenkes RI Jakarta

[6] Zahrawardani D, Herlambang K S and Anggraheny H D 2012 Analisis faktor risiko kejadian penyakit jantung koroner di RSUP Dr Kariadi Semarang J. Kedokt. Muhammadiyah 1(3)

[7] Novriyanti I D, Usnizar F, Irwan I 2014 Pengaruh lama hipertensi terhadap penyakit jantung koroner di poliklinik kardiologi RSUP Dr. Mohammad Hoesin Palembang 2012 J. Kedokt. Kesehat. Publ. Ilm. Fak. Kedokt. Univ. Sriwij. 1(1) pp 55-60

[8] Torry S R V, Panda L and Ongkowijaya J 2014 Gambaran faktor risiko penderita sindrom koroner akut E-clinic 2(1)

[9] Schaefer E J, Lichtenstein A H, Lamon-Fava S, McNamara J R and Ordovas J M 1995 Lipoproteins, nutrition, aging, and atherosclerosis Am. J. Clin. Nutr. 61(3) pp 726S-40S

[10] Yuliani F, Oenzil F and Iryani D 2014 Hubungan berbagai faktor risiko terhadap kejadian penyakit jantung koroner pada penderita diabetes melitus tipe 2 J. Kesehat. Andalas 3(1)

[11]Zahara F, Syafri M and Yerizel E 2014 Gambaran profil lipid pada pasien sindrom koroner akut di rumah sakit khusus jantung Sumatera Barat tahun 2011-2012 J. Kesehat. Andalas 3(2)

[12] Maas A and Appelman Y E A 2010 Gender differences in coronary heart disease Netherlands Hear. J. 18(12) pp 598-603

[13] Chen Z and Boreham J 2002 Seminars in vascular medicine (New Jersey: Thieme Medica

[14] Sudayasa I P, Subijakto S and Sahrul W O A 2015 Analisis faktor risiko merokok, stres dan riwayat keluarga yang berhubungan dengan kejadian penyakit jantung koroner medula 1(2)

[15] Srinivasan M P, Kamath P K, Manjrekar P A, Unnikrishnan B, Ullal A, Kotekar M F, et al 2013 Correlation of severity of coronary artery disease with insulin resistance N. Am. J. Med. Sci. 5(10) p 611

[16] Kayce B, Twiggs J and Orlin B R 2015 Hypertension: the silent killer Updated JNC-8 guideline recommendations 4 